which the lesion is least advanced, one may easily distinguish the decp laycr of the epidermic cells from the interposed cells, while in tlie anastomosing spaces only masses of pavement cells can be recognized.

3. Ulcerations.-Papillary and epidermic lesions are found in the circumference of the ulcerations. As one cones ncarer to the ulcerations in the examination, the embryonal clements beeome more numerous, and finally are so abundant that it is impossible to find any trace of normal dermal elements. On the borders of the ulceration it is scen that the pavement layer disappears, then the decp layer of the epidermis, and finally the papilla. The depth of the ulceration is made up of a layer of very numerous embryonal clements, between whieh are perceived here and there the spaces of epithelial origin already described. It seems at certain points that the embryonal elements united in small rounded masses, as arranged in the form of trberculous nodules, and in fact one sometimes sees, toward the eentre, yellowish opaque masses made up of elements which seem very like giant-eells.

4. Lesions of the Subcutaneous '/issue. - The sudoriparous glands are inflamed, their epithelium being in process of proliferation and ilcsquanation. It will often be found that the embryonal portions have followel thcir excretory canals from the surface toward the deeper portions, anrl lymphoid masses are formed around the glands. Other elcments are found along the vessels, others still are completely isolated. It is probable that some may be found in lymphatic trunks. The cellular tissue appears to be thickened, and the fasciæ are indistinct; they secm to bc glued up with a semi-opaque celloid substance. The layers are well coloured by violet and methylaniline; this colour is found in the walls of some sudoriparous glands, of arterioles, and in the thiukened layer which the stratum lucidum forms. It seems, therefore, that amyloid degeneration exists in these different points.

The histological cxamination appears to be in favour of the similarity which was stated, in the beginning of this notc, to exist between pseudo-clephantiasis and lupus scrofulosis. Are these lesions related to tubcreulosis? Boiteux reports a case in the Revue de Chirnrgie, 1881, of a young girl having ulcerations and strumous osteitis of the toes which seemed to bc due to successive cuscs of erysipelas or lymphangitis en masse. There was chrouic œdema with dermatitis of pseuclo-elcphantiasic appcarance. Histological examination showed the existence of abundant embryonal infiltration of the skin, and numerous tubercular follicles. With this cuse is cited one of true elephantiasis, contracted in a warm elinate, in which cutaneous sclerosis predominated, the comparison of the two making the difference very striking.-Le Progrès Mled., Dec. 1, 1883.

\title{
SURGERY.
}

\section{Removal of the Tongue.}

Mr. W. Morrant BaKkR read a paper on this subject at the fifty-first annual meeting of the British Medical Association, in which he said that the important matter in all cases is, that there shall be a large margin of healthy tissue removed with the cancer; and this is quite easy of performance by any method. Such cases, however, are exceptional; and, in the others, in which the disease extends at least to the level of the last molar tooth, or invades the mucous membrane of the floor of the mouth or the gum, or in whieh there is more or less abnormal 
fixity of the organ to neiglbouring parts, the choiee of operation is of eonsequence. As before, however, the most important question, by far, is this : How ean the disease be most eompletely removed without undue risk to the patient's life?

I do not propose to eonsiler here the eomparatively rare eases in whieh the disease eannot be removed without complete division of the lower jaw. Such eases form a class by themselves, and may or may not be best dealt with by median division of the tongue and the use of the ecraseur. I will assunte that section of the bone is not neeessary, and that the operator has decided to use the ecraseur. Under such eireumstances, the following is the plan whieh I believe is the best to be adopted :-

A gag having been introdueed, and any jagged teeth likely to be in the way of the operator having been extracted, two threads are passed through the tongue, about an ineh belind the tip and half an inch on each side of the middle line. One of these looped threads is now given to an assistant to hold tightly ; and the operator, holding tle other, seores the dorsum of the tongue with a blunt-pointed sealpel, exaetly in the midlle line-extending the "cut" well through the mucous membrane in the surface of the muscular substance, and clividing the tip freely down to and through the middle line of the frenum. The ent may be extended back as far as the operator deems necessary-say, for an inch beyond the level of the posterior edgre of the eancer. He then tak es both threads, one in each hand, and, using the forefingers much in the same way thut he would for tightening a ligature on a deep vessel, he splits the tongue into two halves. At this strge of the operation, the hemorrhage is nsually very trifling, if the operator has taken care to cut along the middle line; ancl, even if lie is a little to one side or the other, the divided vesscls are small and easily ligatured. The thread which tethers the diseased half of the tongue is now pulled quite taut, either by the operator or his assistant; while the former, with blunt-pointed seissors, snips, as far as he eonsiders neeessary, the mneous membrane and muscnlar fibres which conneet the tongue witl the anterior part of the lower jaw behind the symplysis, after the manner suggested many years since by Sir James Paget. He then "runs" the scissors along the floor of the mouth, immediately beneath the mucous membrane, keeping close to the ramus of the $j a w$, until he has eut, if possible, to a point beyond the level of the posterior edge of the eancer. Then, with his forefinger and by occasional suips with the seissors, he frees the tongue as completely as may be requisite from its attachments in front and at the silles and in the floor of the mouth. The clief point aimed at, of eourse, ut this stage of the operation, is to free the diseased half of the tongue in such a manner that it may be surrounded by the loop of the ecraseur at some distanee behind the disease, and without danger of the cord slipping forwarl so as to embrace the neighbourhood of the cancer, and much less the cimeer itself.

This is by far the most important jart of the operation; and, should the surgeon be in doubt about his having sufficiently freed the tongue with his finger, he should again introduce the scissors, and cautionsly divide any inuscle or other structure which prevents the due loosening of the tongue. Having now freed the tongue sufficiently, one, and sometimes two, blunt curved needles (of the pattern shown) are now made to perforate it at some distance, an inch, or more if possible, behind the eancerous mass; and the loop of the ecraseur is now slipped over the diseased half of the tongue, and adjusted behind the needles. With the screwing-up of the ecraseur, this part of the operation is now eompleted, with the exeeption that, very eommonly, at least when whipcorl is employed, the main vessel and some other tissue, perhaps nerve-fibres, are pulled through the end of the ecraseur after tle softer substance of the tongue has been 
crushed through. Under tbese circumstanees, a double ligature should be passed with an aneurism-necdlc, and the strand of vessels and nerves divided between the two knots, when the eraseur will, of course, at once comc away, and the main vessels will be left on the face of the stump securely ligatured.

In the event of botb sides of the tongue requiring removal, an ecraseur should now be slipped over the other balf after it has been sufficiently freed from its attachments, and the diseased part guarded by a blunt-pointed needle. This part of the operation, on account of the space gained by the removal of half tbe organ, can be performed witl comparative ease and rapidity.

After the removal of the tongue, wholly or in part, as the case may be, it should be carefully examined with reference to the question of how much healthy tissue has been removed with the cancer; and the floor of the mouth and stump of the tongue should be carefully examined also, with the same object in view. In frceing tbc tongue from the floor of the mouth, portions of mucous membrane, sublingual glands, and the like, are often loosened; and these can be readily dissected away when space has bcen gained by removal of the tongue. Lymphatic glands should also be searched for, especially in the submaxillary fossa. Should any be found, now or previously, an incision should be made through the skin over them, and they should be carefully cnucleated.

In many cases, the removal of the tongue is greatly facilitated by previonsly dividing the cheek from the angle of the mouth to the anterior border of the masseter-a little below the line of the parotid duct-as recommended by Collis, Gant, Furneaux Jordan, and many othcrs. This should be, I venture to think, alway's done if the disease extend far back. The scar is afterwards but trifling, if a little care be taken in applying the sutures of union.

It is often advisable, especially when the disease has advanced into the mucous membrane of the floor of the moutl, to extract three or four of the neighbouring teeth from the lower jaw; and, when the disease approaches or invades the gum, much valuable sjace may be gained (inuch more than would be imagined by one who had not done it) by cutting away also a portion of the alveolar border of the lower jaw.

With regard to the ecraseur, the ehoice of instrument is a matter of secondary importane ; at the same time, it is not unimportant altogether. The instrument which I have been in the labit of using of late is of very moderatc length and weight, and is somewhat curved on the flat near the end. (Pattern slown.) The pattern is almost identical with that which my colleaguc Mr. Harrison Cripps has recommended for removal of the lower end of the rectum; but I prefer working both limbs of the looped cord at the same time, and therefore have a double instead of a single hook, and have no perforations at the shoulder of the instrument. The material of the cord which I much prefer to any other is a thick kind of whipcord. (Specimens shown.) It is more easily natnageable than any kind of wire, and very much more than the linked elain. For some years past I bave not met with any case in which the cord has broken under the strain of cutting through the tongue; nor have I ever had, so far as I can remember, any case of recurrent hemorrhage after the operation. This last advantage I am inclined to attribute partly to the fuct that a whipcord or wirc loop, and more especially whipcord, will, usually, after the tongue has been crushed through, drag through the end of the ecraseur a small strand of tissue containing the chief vessels, to which a ligature can be applied before the removal of the ecraseur. The bcing able to tie the main vessel at the end of the operation enables the operator to screw up the ecraseur more rapidly than he wonld have otherwise ventured to do. I tbink it is a good plan to apply a ligature to the main vessel, 
if it can be seen on the face of the stump, if it has not been tied before the removal of the ecraseur.

I have now removed the tongue, wholly or in part, thirty-six times, and in all but three by the method here described. Of the thirty-five patients (one of whom was operated on twice, at an interval of four years and a half, thus making the thirty-six operations), thirty recovered, and Gve died. Of the deaths, one was from diphtheria, beginning abont ten days after the operation; two from septicæmia; and one from general debility, arising thiefly from other causes than the cancer of the tongue; and one died six weeks after the operation from subacute pneumonia, the symptoms of which began about a week after the operation, with congh and slightly raised pulse and temperature, and consolidation of the ba sc of the left lung. All the symptoms proeeeded quictly to the last, the patient having recovered quickly from the immediate effects of the operation, and being able to take carriagc-exercise for some weeks to within a day or two of his death. The sputa were offensive, and I lave no doubt that the inflamed lung-tissue had in part broken down.-British Med. Journ., Oct. 20, 1883.

\section{Colotomy in Syphilitic Ulceration of the Rectum.}

In a paper on this subject Dr. Eugene Hans says that it has not yet been deternined whether the so-ealled syphilitic uleeration of the rectum, which is exclusively confined to females, and can often be observed in syphilitic women, is certainly of syphilitie origin or not; whether they must be attributed to the secondary or tertiary period; or arise from mueous patches, condylomata, or gummous nodules; or whether they are not of a syphilitic nature, and arise from infection with gonorrlieal secretion, or are the product of infeetion from a soft uleer, is still unsettled.

Hahn has seen fifty eases and made about thirty autopsies, and is confident that he has scen some eases of the so-called syphilitie nleeration of the rectum which eould not have been attributed to a syphilitic origin.

The views of different authors on this question differ widely. Some, as von Birensprung and Fournier, hold to the syphilitie nature of this ulceration, and assign it in different periods to mueous patehes or to gummata. Fournier ascribes it to the tertiary period, and distinguishes between these uleerative or gummatous forms, and those called by him the ano-rectal syphiloma, which begin in the submucous tissue. Pathological anatomy has not yet determined this question; as Virelow says that he has hat no opportunity to observe the first stage of the process, and nust, therefore, leave it doubtful whether the ulceration ordinarily has a condylomatous or gummous beginning, or whether it is chiefly of a secondary nature. Its almost exclusive appearance in women favours the primary nature of the disease. As far as the customary local and general treatment is concerned the results are usually very poor.

Antiseptics, astringents, and cauterants, in powder and ointments, slitting of the stricture, the sharp spoon, and the actual cautery, bougies, iodide of potassium, inunctions and injections, all alike seem to be equally inefficacious in many of these cases. The purulcnt discharge continues, and the patient goes on from bad to worse. Some die from the great drain on the system, with amyloid degeneration of the different organs, others of pyæmia or septicæmia. It occurred to Hahn that if the fecal matter could be kept from the surface of the ulcers of non-syphilitic nature, they could be cured by judicious treatment; and by antisyphilitic remedies; if they were of speeific origin, they could be cured. $\mathrm{He}$, therefore, proposes colotomy, and reports the following case :-

A woman, at. 25 years, prostitute, with a severe rectal affection, came under 